\title{
DOCK8 Gene Mutation
}

National Cancer Institute

\section{Source}

National Cancer Institute. DOCK8 Gene Mutation. NCI Thesaurus. Code C128819.

A change in the nucleotide sequence of the DOCK8 gene. 